\title{
An unwelcome export success
}

Is India now one of the world's chief and opportunities. sources of migratory technical skill? According to two recent studies, three out of ten engineering graduates produced by the Indian Institute of Technology (IIT) Bombay since 1970 have settled abroad, while the brain drain from IIT Madras varied from 20 per cent during 1963-67 to 35 per cent in 1983-87. The five IITs are the country's most distinguished engineering schools.

Things are much the same at all five IITs. Thus Professor M. C. Nigam, director of IIT Delhi, estimates that the exodus from his institute has been steady at 30 per cent. And it is generally agreed that nearly a quarter of the engineers trained at all the five IITs (the others are at Kanpur and Karagpur) take a plane to the West each year.

Computer scientists head the list. In a recent study, Robert K. Perkins of the University of California, Berkeley, found that 91 per cent of first-year computer science students of IITs and the Jadhavpur University planned to emigrate when they were qualified. In fact, 70 per cent of them at Jadhavpur ended up going abroad.

The situation is much the same in medicine. A recent study by Professor Veena Kalra of the All-India Institute of Medical Sciences (AIIMS) in New Delhi discovered that 45 per cent of graduates from the institute since 1971 have emigrated. She says that the brain drain, which reached a peak at 80 per cent ten years ago, continues but at a lower rate.

"Considering that it costs taxpayers $£ 3,000$ to educate one IIT graduate and twice that amount for a medical student, India has repaid through export of human capital more than the total aid it received from abroad," says S. Biswas, an education consultant in Delhi. "India, no doubt, produces more professionals than it needs," he says, "but the 2 per cent of professionals who leave each year represent the cream."

Meanwhile there are fears that the brain drain will accelerate because of the recent economic reforms, which encourage the entry of multinational corporations into India. "When multinationals come to India in a big way, they will draw on local talent and, after a few years, relocate them to Singapore, Korea or the United States," says Professor Nigam.

While the migration continues, its pattern is changing. Thus there has been a recent growth of migration towards Australia, which has opened its doors to technically qualified people, and to Singapore, which has begun giving work permits to Indians. Nigam believes that the brain drain will continue unless Indian industries modernize and unless the government offers world-class facilities negligible.
One feature of the migration from India now apparent is that people seize the earliest opportunities to leave. Thus the bulk of the exodus from India to the United States is made up of fresh graduates from IITs and other institutions of higher learning. Once people are established in posts at universities, the Council of Scientific and Industrial Research (CSIR) or the councils of medical or agricultural research, the risk that they will migrate appears to be

Past schemes to stem migration appear to have had little success. Indeed, the Indian government does not seem to be unduly worried; its new technology policy statement offers no prescription for reducing the brain drain.

"The brain drain is a natural process and cannot be plugged", says S. C. Mazumdar of CSIR, who is in charge of the TOKTEN (transfer of knowledge through expatriate nationals) project to reverse the brain drain. But in 13 years, he has been able to tempt only 500 expatriates to accept short-term assignments in Indian laboratories. The project is in any case to be wound up in December 1994. Another government scheme, launched two years ago to lure expatriates to industry, has yet to yield results. The 35-year-old "scientist pool scheme", designed to find jobs for

\section{A gold mine of information}

SElling Russian science to the West India's National Informatics Centre (NIC) in New Delhi is planning to exploit Russia's need of cash by acting as an information broker.

The calculation is that there is a huge amount of saleable information on science and technology (S\&T) which the world is not aware of because it is all in Russian. And several companies in the United States are ready to pay money for translated Russian literature in the belief that it contains ideas or inventions they can exploit commercially. According to N. Seshagiri, NIC's director-general, there is a goldmine of information in theses, laboratory reports, journals and other Russian-language documents that the Russians now wish to sell.

NIC has worked out a two-way arrangement under which it will translate the Russian reports, create appropriate databases and then make these available to vendors in the United States. We are just a middleman, says Seshagiri. From whatever the US companies pay, NIC will subtract a service charge and hand over the rest to the Russians. Seshagiri returning scientists, has so far succeeded in resettling about 7,000 Indians, but many have since emigrated again.

Mazumdar nevertheless emphasizes that even when Indian expatriates in the United States do not want to return, they are eager to help in other ways. He mentions, for example, their willingness "unofficially" to arrange for training of their countrymen who happen to be visiting the United States.

Even so, the government's hopes that it would keep able people at home by the creation of new technical agencies, in fields such as ocean development, environment and biotechnology, appear to have been disappointed.

But there are some exceptions. The National Informatics Centre (NIC), which has 3,200 computer professionals, boasts of having lost only 60 in 15 years. In contrast, 15 per cent of the staff of Tata Consultancy Service, a private computer company, have gone abroad despite better pay than those at NIC. "People do not want to leave NIC, even though their paychecks are not thick," says $\mathrm{N}$. Seshagiri, NIC's chief. "We give them intellectually challenging problems in frontier areas of technology, and we have the best equipment and a good personnel and promotion policy. We have proved that brain drain can be stopped under the right conditions," he says.

K.S.J.

\section{says it will be a handsome amount.}

Four Russian institutions, all in Moscow, have entered into this deal with NIC. They are ICAD (Institute of Computer-Aided Design) and VINITE (a science and technology information organization), and two institutes of the Russian Academy of Sciences. Initially, the agreement will run for two years, but will be extended if there is a sufficient demand for it. NIC has negotiated with three US companies, who will be in Delhi this month to finalize the agreement.

NIC is opening an office in Moscow and installing computer terminals that will be linked to NIC's Cyber-730 host computer. Full translation of Russian texts will be provided on request. To start with, NIC will prepare databases on fluid mechanics, aerodynamics and informatics.

According to Seshagiri, India and Russia will invest 1 million each in this joint venture, which he says will give a return of 10 million annually beginning in 1994. The profits will be shared between Russia and India in the ratio of 60:40.

K.S.J. 